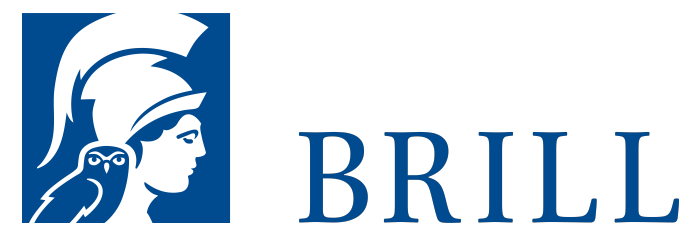

\title{
Eine Statustheorie moralischer Rechte
}

Author: Hubert Schnüriger

Rechte spielen in den meisten normativen Debatten eine prominente Rolle. So stellt sich angesichts der globalen Armut etwa die Frage, ob Menschen ein Recht auf Ernährung haben. Umstritten ist aber auch oft, wer oder was überhaupt Rechte haben kann. Können zum Beispiel Tiere oder Föten Rechte haben? Das Buch versucht zu klären, worum es in diesen Debatten geht, wenn sie als Auseinandersetzungen über Rechte geführt werden. Im ersten Teil werden die klassischen Theorien subjektiver Rechte diskutiert. Als Antwort auf unterschiedliche Schwächen dieser Theorien wird unter dem Titel "Statustheorie“ ein eigenständiger Begriff subjektiver Rechte eingeführt und verteidigt. Moralische Rechte bringen der Statustheorie gemäss zum Ausdruck, dass Pflichten um der Rechtssubjekte willen bestehen. Der zweite Teil widmet sich der Frage, welche Rolle moralische Rechte in der konkreten Begründung von Handlungen spielen. Hier wird nicht nur eine Typologie von praktischen Konflikten entworfen, sondern auch das Verhältnis des Rechtsbegriffs zu anderen zentralen Begriffen erläutert und die Unvereinbarkeit von moralischen Rechten mit konsequentialistischem Denken ausgewiesen.

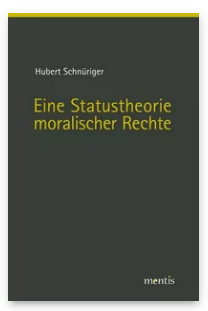

Pages: $35^{8}$

Seiten

Language:

German

Subjects:

General, Philosophy

Publisher: Brill | mentis

E-Book (PDF)

Released online: 27 Jan 2014

ISBN: 978-3-

89785-848-o

List price

Paperback

Publication date:

27 Jan 2014

ISBN: $978-3^{-}$

$89785^{-825-1}$

List price 
For more information see brill.com

Order information: Order online at brill.com +44330 333 0049 | customerservices@brill.com Submission information: brill.com/authors

Titles published by Brill | Fink, Brill | mentis or Brill | Schöningh: +49(o)715413279216| brill@brocom.de 